\title{
TEUCHITLÁN AND CENTRAL MEXICO: GEOMETRY AND CULTURAL DISTANCE
}

\author{
PHIL C. WEIGAND
}

The highland lake districts of Jalisco and Nayarit were focal points for complex social developments during the Classic period, developments firmly rooted in long sequences of exotic Formative cultures (Kelly 1980; Oliveros 1974; Scott 1985; Mountjoy 1972; Galván 1976 and 1984; Weigand 1977 and 1985). It is the purpose of this study to outline the apparent degree of relationships between these Classic period societies and the Central Mexican polity(s) called Teotihuacan.

The area under consideration is one of natural wealth in strategic resources. Fertile lake basins -fertility in soils, aquatic foods, water, and demographic potential-about high mountains and deep canyons. The area is characterized by tightly packed, highly variegated ecological zones. Abundant in addition are rare resources; copper, silver, gold, malachite, azurite, chrysacola, pyrite, hematite, opal, optical quality quarts, and high quality obsidians (Weigand 1985; Weigand and Spence 1982). The Formative cultures of this region show early an intensive interest in many of these rare resources. In the lake basins due west of Guadalajara are side-by-side sites and site areas that show Capacha (cf. Kelly 1980) and El Opeño (cf. Oliveros 1974) cultural characteristics. Since it is thought that these Early Formative complexes are coeval, it is interesting to note that their diagnostic characteristics are not found in the same sites. They are all located on the terraces of lakes in close proximity to excellent obsidian outcrops.

Social differentiation became far more notable during the Middle Formative, or San Felipe phase, culminating in a distinct architectural style during the Late Formative, or El Arenal phase (ca. 300 B.C. to A.D. 200). This architectural style will be discussed in some detail because of its consolidation during the Classic periods (the Ahualulco phase, $c a$. A.D. 200 to 400 , and Teuchitlán I phase, $c a$. A.D. 400-700) and its uniqueness in Mesoamerica, which gives it a "signature" character that also marks clear geographical boundaries (figure 1). Hundreds of sites, often differentially developed from one another, illustrate these diagnostic architectural characteristics. The differen- 
ces between the architecture of the Late Formative and the Classic periods are in monumentality, expressed as a shift from investment in shaft-tombs to large surface structures, plus an implosion of population. This implosion concentrated people into six major habitation zones, one of which, the Teuchitlán-El Refugio zone, covers 32,000 ha. of precincts, residential compounds, terrace systems, check dams, and chinampas. The nucleus of this habitation zone is $c a .3,000$ ha. into which almost all of the high architectural activity is concentrated. The other habitation zones are considerably smaller, at 3-5,000 ha. each, with cores of 300 to 500 ha. Population estimates, based upon an assumption of $60 \%$ coevality in residential compounds, are 40 60,000 individuals, about half of whom were concentrated within the nucleus of the Teuchitlán-El Refugio zone. Within that zone, four tiers of precinct architecture have been defined, though all share the five diagnostic features (discussed below, and see figures 2, and 3), and a high degree of symmetry and proportionality in plan.

The five diagnostic features are:

1) a circular pyramid, terraced, and flat-topped with an occasional semi-subterranean room on the top, which is surrounded by,

2) a circular, elevated patio, which is made from clean, tamped earth; which in turn is surrounded by,

3) a circular platform/banquette, completing an arrangement of three concentric circles, or a family of three circles with a radical center, which display patterned proportionality; and atop this final circular feature are between:

4) eight to sixteen rectangular, terraced pyramids/platforms with stairways into the patio; underneath of which are:

5) re-enterable family crypts with modest shafts and at least one side chamber for the actual burials and offerings. ${ }^{1}$ (Figures 4,5 and 6.)

For a more detailed and contextual discussion, see Weigand (1985).

1 The relationships between the shaft-tombs and the Late Formative ( $\mathrm{El}$ Arenal) and Early Classic (Ahualulco) phases' circular architecture has been demonstrated with three information sets:

a) José Corona Núñez's work (1955, Tumba de El Arenal. Etzallán, Jalisco. Informes \# 3, INAH.), plus that of Long (1966), found two monumental shaft-tombs directly under side-by-side platforms of the major architectural circle at El Arenal. (See figure 4.)

b) Our own survey has produced dozens of more examples of exactly this same association at dozens of more sites. 
It must be stressed that the concentric circles are organized as families of circles, laid out from radical centers. There were strict, formal rules governing proportionalities between the radii of the components. (elements \#1, \#2, and \#3) p $^{2}$ plus stricter rules concerning the symmetrical placement of the platforms/pyramids (element \#4) atop the circular platform/banquette (element \#3), (figures 7 and 8). The end effect is one of grace and elegance, a "classical" attainment in architecture not duplicated elsewhere in Mesoamerica, nor in the world. The closest complex formats elsewhere in the world appear to be the circular city plans of several Near Eastern sites, such as Baghdad, Gur, and Darabjerd (plans in: Johnston 1983: 16-18), and the two famed 1765 Patte plans for French royal palaces (plans in: Tzonis and Lefaivre 1986: 270-271). Classical architects, such as Alberti (1986) and Palladio (1965, and Ackerman 1966), illustrate some circular buildings, in plan and profile, but only lightly discuss the generative grammars (a la Chippindale 1986; Stiny 1976; and Barnatt and Moir 1984) that led to their formulations. The discussions of polar grid systems by Serlio in 1537 and the generative potentials in Cesariano's 1521 models (cited in Tzonis and Lafaivre 1986, chapter 1) seem to be the most closely reasoned conceptual discussions of the under-writing

c) The looters themselves state that these platforms are the first places that they excavate, because decades of experience has taught them about the association. It is important to note, though, that this association is not $100 \%$. The shaft-tombs of earlier phases have different patterns of architectural association. The San Felipe (Middle Formative) shaft-tombs are most frequently found beneath circular platforms that apparently are free-standing (Weigand, 1989, "Architecture and Settlement Patterns Within the Western Mesoamerican Formative Tradition", in: Martha Carmona Macías, eda., El Preclásico o Formativo. Avances y Perspectivas, MN.VINaH, pp. 3964.), and not organized as elements within families of circles. The still earlier El Opeño (Early Formative) phase tombs appear to be associated with no architecture whatsoever. Even in the El Arenal phase, some of the monumental shaft-tombs are located in the patios, or under platforms away from the circles, though it is very important to note that they are still associated with the architecture of the period. Therefore, we must specify the time period involved when discussing the type of surface architecture associated with the shaft-tombs. In general, however, the greates and most monumental tombs are found as elements within the architectural circles.

2 In reference to the three concentric elements, aside from the symmetry in the placement of the platforms above the banquette, one should note the proportionality of diameters of Banquette to Patio to Pyramid (see Figure \#2). Reading across the entire building's diameter, the banquette is one measure (no matter what that measure may be), the patio is one measure, the pyramid is 2.5 measures, the patio is another measu$\mathrm{re}$, and the banquette is another measure. In other words, the formula 1:1:2.5:1:1 was followed rather closely, and, as a formula, apparently used in the formal planning and design of the circles. 
principles of architectural circularity during the Renaissance. Remarkable buildings from Classical antiquity, such as the Pantheon in Rome (cf. MacDonald 1976), and Renaissance Italy, such as Brunelleschi's Church of san Maria degli Angeli in Florence (14341436, of. Clark and Pause 1985), however, only resemble the Teuchitlán Tradition's circular buildings in a most superficial fashion. In reality, there exist no comparable structures for any time period anywhere else in the world, including the rest of Mesoamerica. These formal buildings are completely and truly unique in the Mesoamerican (and world) architectural repertoire. This architectural tradition was so unmistakenly different and exotic from its neighbors, near and far, as to offer highly visible boundaries for its distribution; and, in effect, an experimental and innovative style of unusual beauty, and certainly a "signature" style for a well organized society(s).

I have discussed this architectural pattern here in some detail because of its significant difference in morphology from anything even remotely associated with the architecture of the Teotihuacan style (Millon 1973; Sanders, Parsons, and Santley 1979). Since architecture is such a fundamental and basic social investment in resources and, as importantly, ideology, this dramatically different world view, embodied architecturally, appears to portray considerable distance from that of Teotihuacan. While occasional round structures are found in the Teotihuacan repertoire, their rarity underlays their lack of centrality in formal design and precinct planning. Architectural morphology is reflected in spatial design systems as an entire class. The Teuchitlán Tradition's reliance on concentric circular architectural morphology is at the opposite extreme of Teotihuacan's rectangular/square building plus grid geometry. There is more to this observation than the question of prehistoric design; there is the entire question of the ideological underpinnings for formal design. Both Teotihuacan and Teuchitlán appear to have had formal, rather than vernacular, design as both embody working from abstract architectural conceptions and creating specified designs to be tightly replicated by others, ut in pluribus, whereas vernacular architectural design is the process of design inseparable from construction (Rudofsky 1964; Downing 1969; Gauthier-Larouche 1974; Moholy-Nagy 1957; Mercer 1975; Deetz 1977; Wells 1987). Vernacular architectural designing displays more variability, and, while it can be very conservative, the governing rules are most often implicit. Both Teotihuacan and Teuchitlán are highly regular in symmetries, proportionalities, 


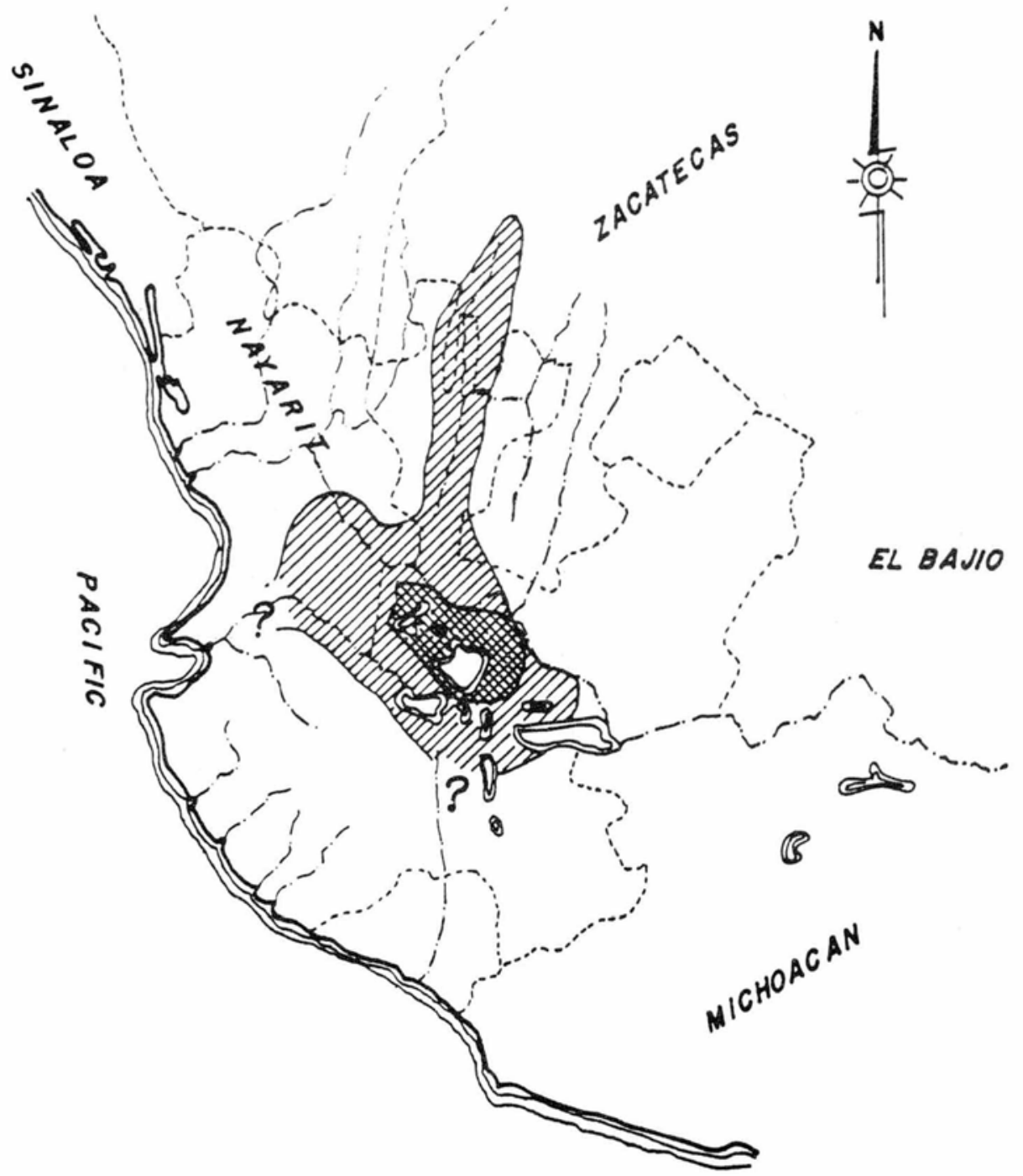

THE TEUCHITLAN

TRADITION

CORE

WESTERN MEXICO

\section{CLASSIC PERIOD CIRCULAR CEREMONLAL COMPLEX \\ RON}

1. This architectural style will be discussed in some detail because of its consolidation during the Classic periods and its uniqueness in Mesoamerica, which gives it a "signature" character that also marks clear geographical boundaries. 


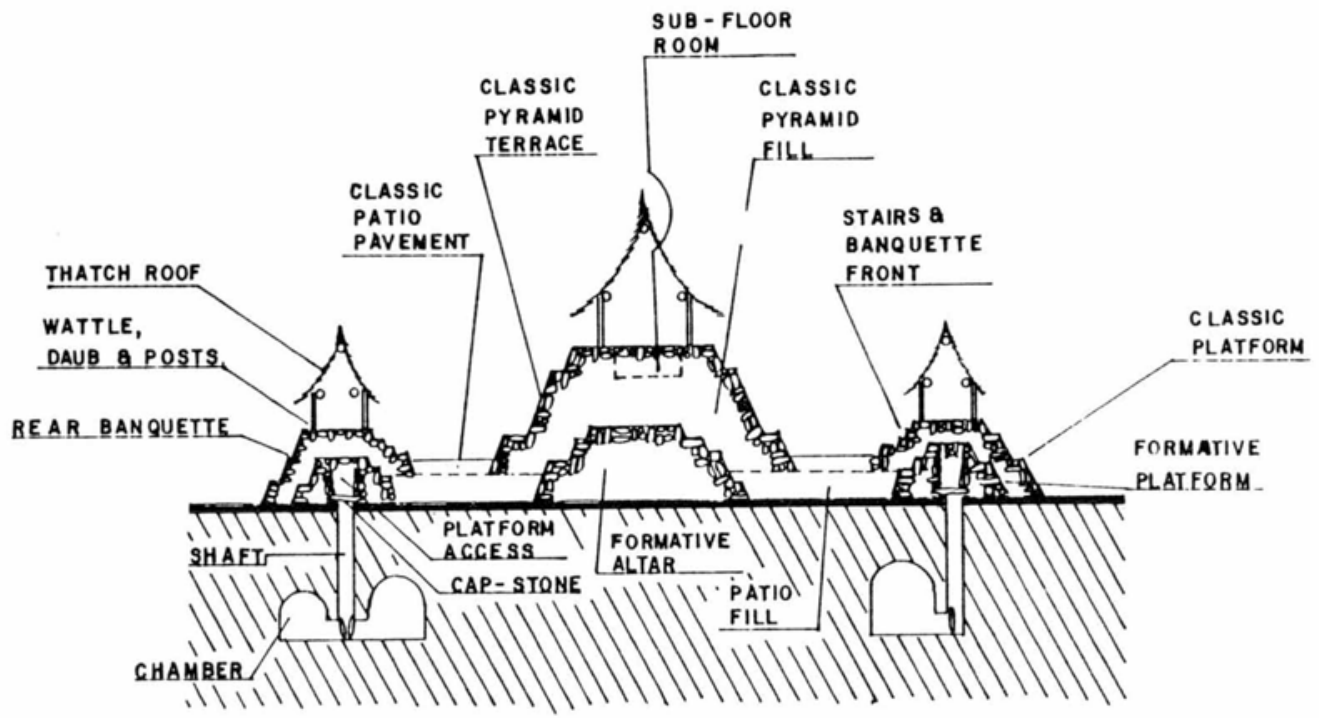

CROS S

SECTION

THE TEUCHITLAN TRADITION

WESTERN MEXICO

2., Teuchitlán.

Figs. 2 and 3: Within that zone, four tiers of precinct architecture have been defined, though all share the five diagnostic features and a high degree of symmetry and proportionality in plan. 


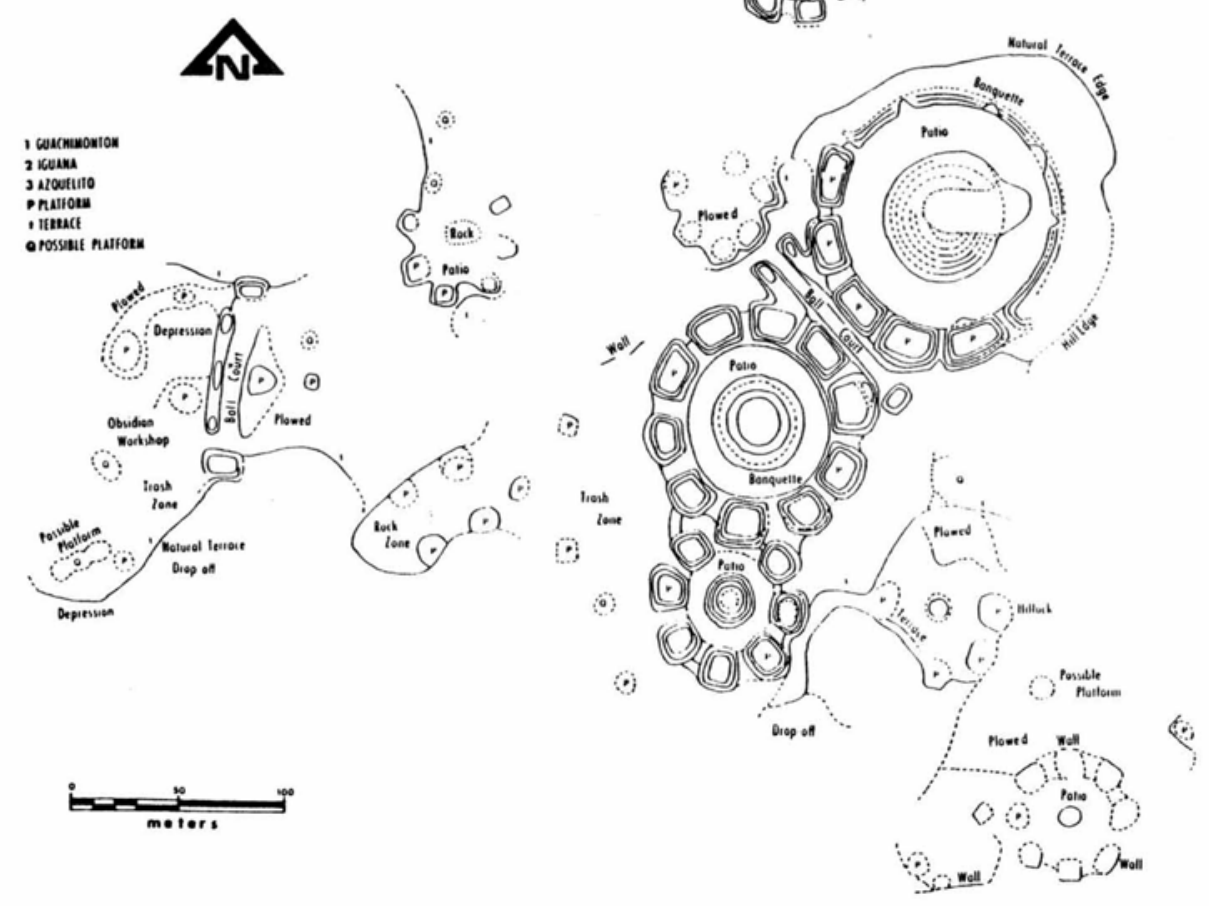

3. Guachimonton complex, Teuchitlán. 

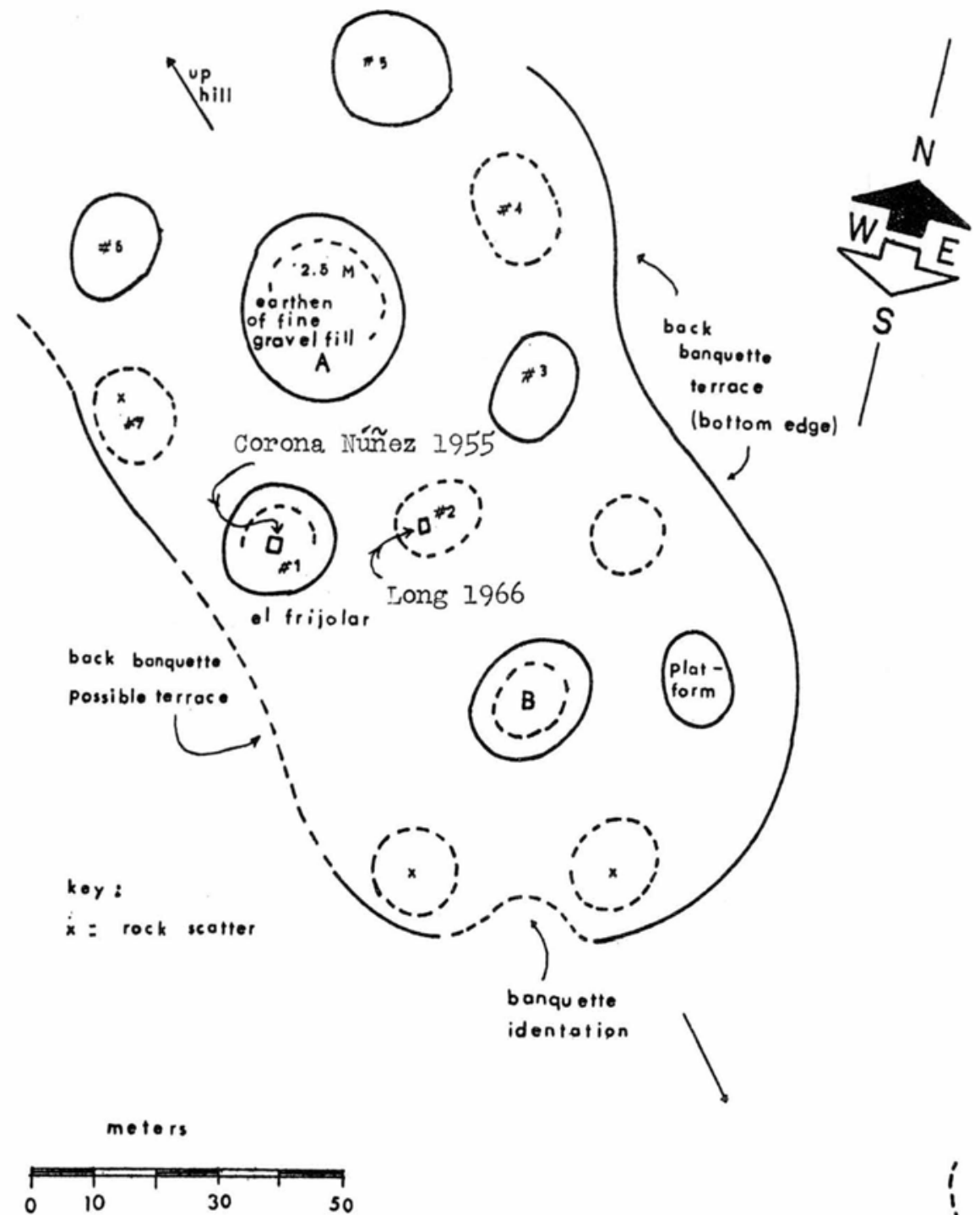

4. El Arenal.

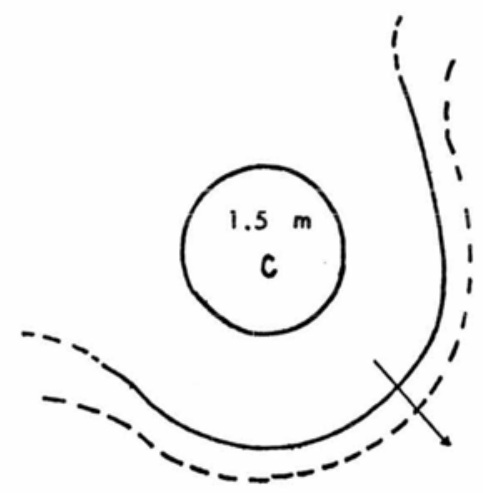

Figs. 4, 5 and 6. Re-enterable family crypts with modest shafts and at least one side chamber for the actual burials and offerings. 
DOI: http://dx.doi.org/10.22201/iie.18703062e.1991.62.1601

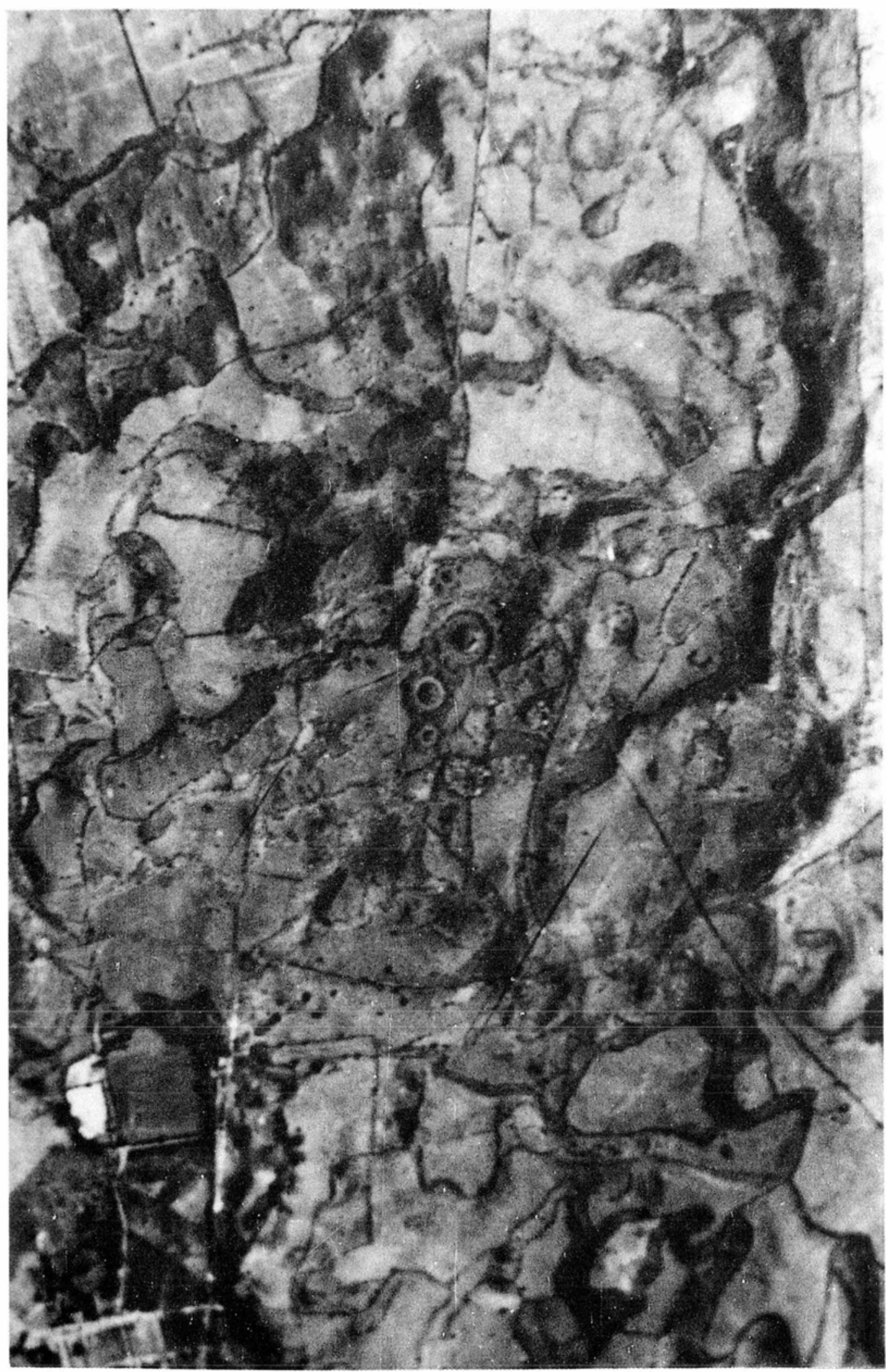

5. Guachimonton complex, Teuchitlán. Vertical air photo. 
DOI: http://dx.doi.org/10.22201/iie.18703062e.1991.62.1601

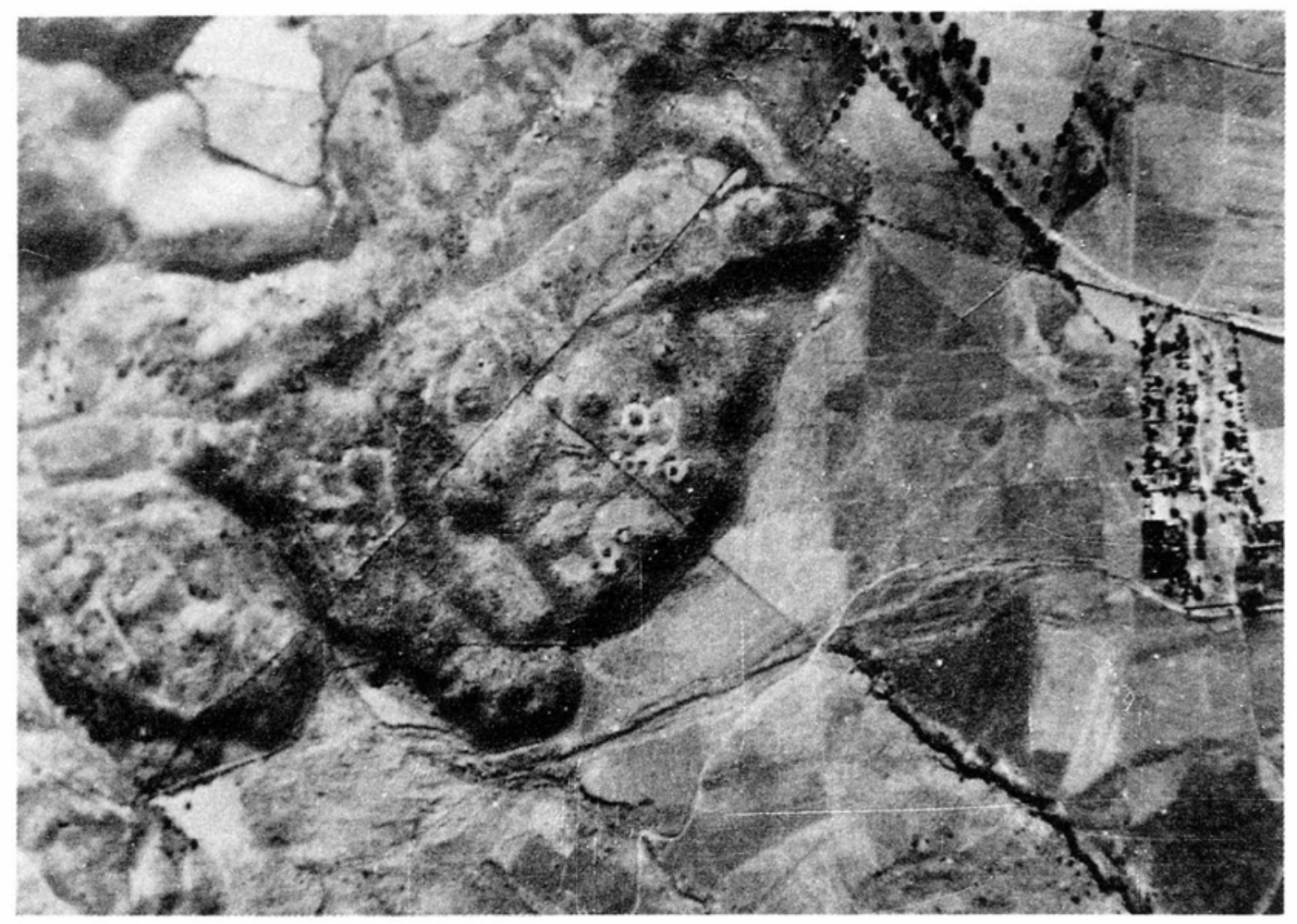

6. La Providencia. Vertical air photo.

Figs. 7 and 7a. Atop the circular platform/banquette (element \#3). 
DOI: http://dx.doi.org/10.22201/iie.18703062e.1991.62.1601

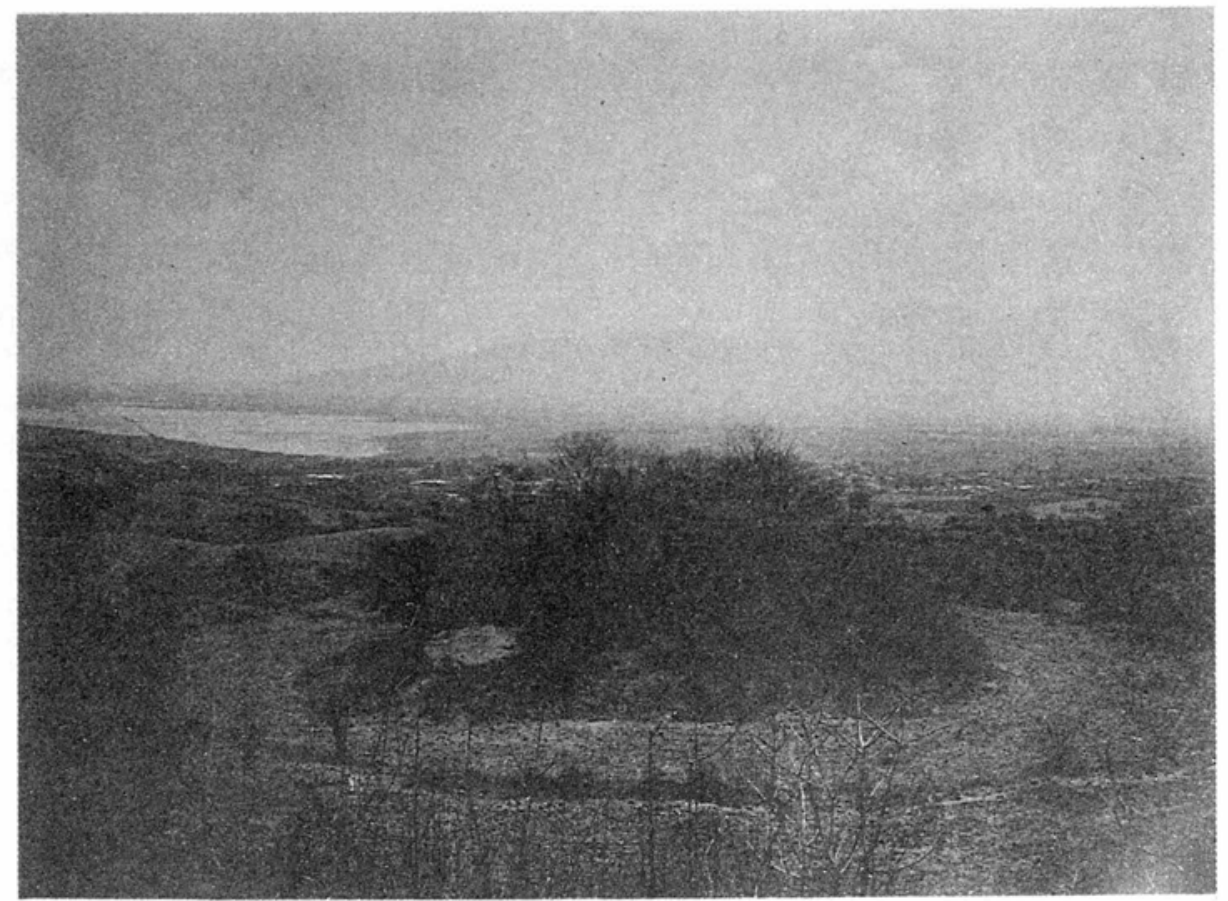

7. Guachimonton. Teuchitlán.

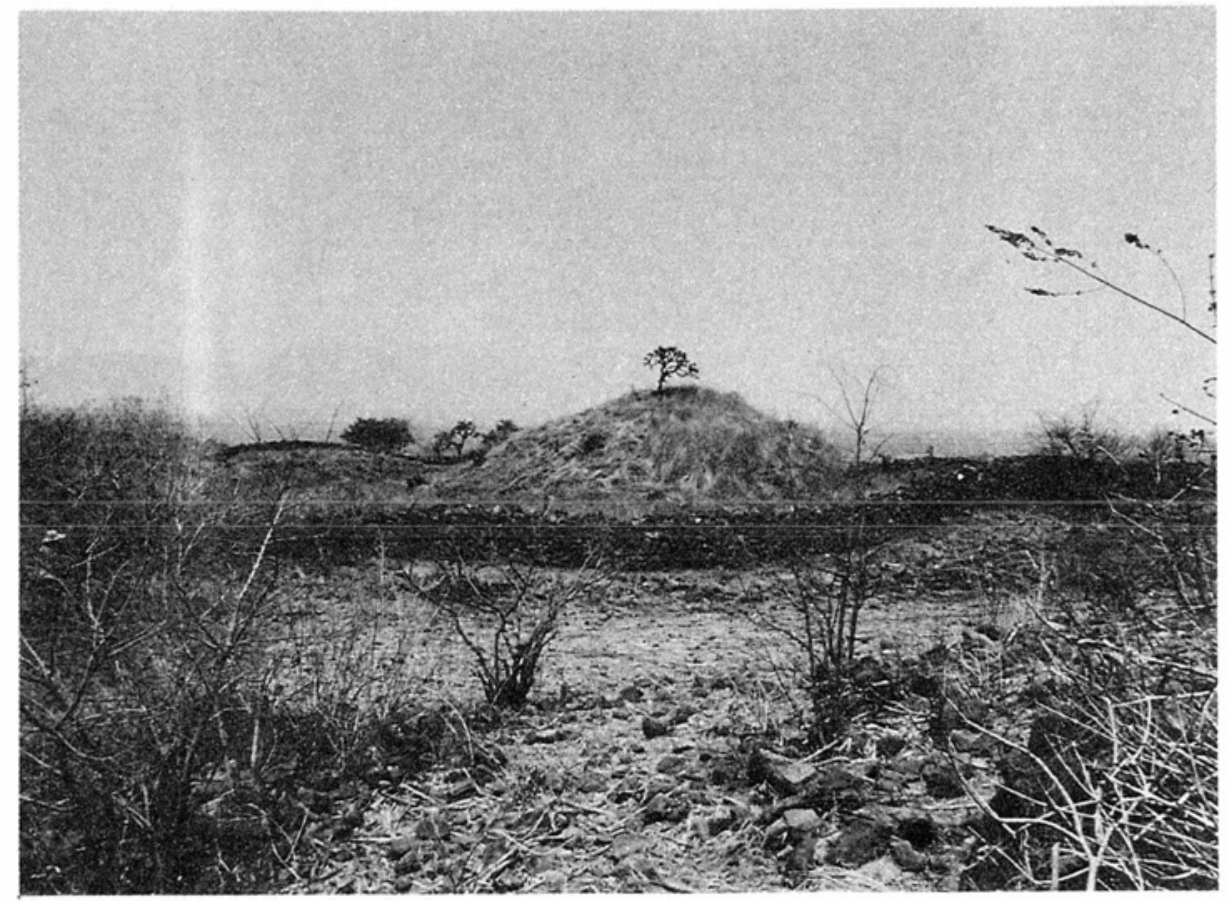

7a. Teuchitlán. 
DOI: http://dx.doi.org/10.22201/iie.18703062e.1991.62.1601

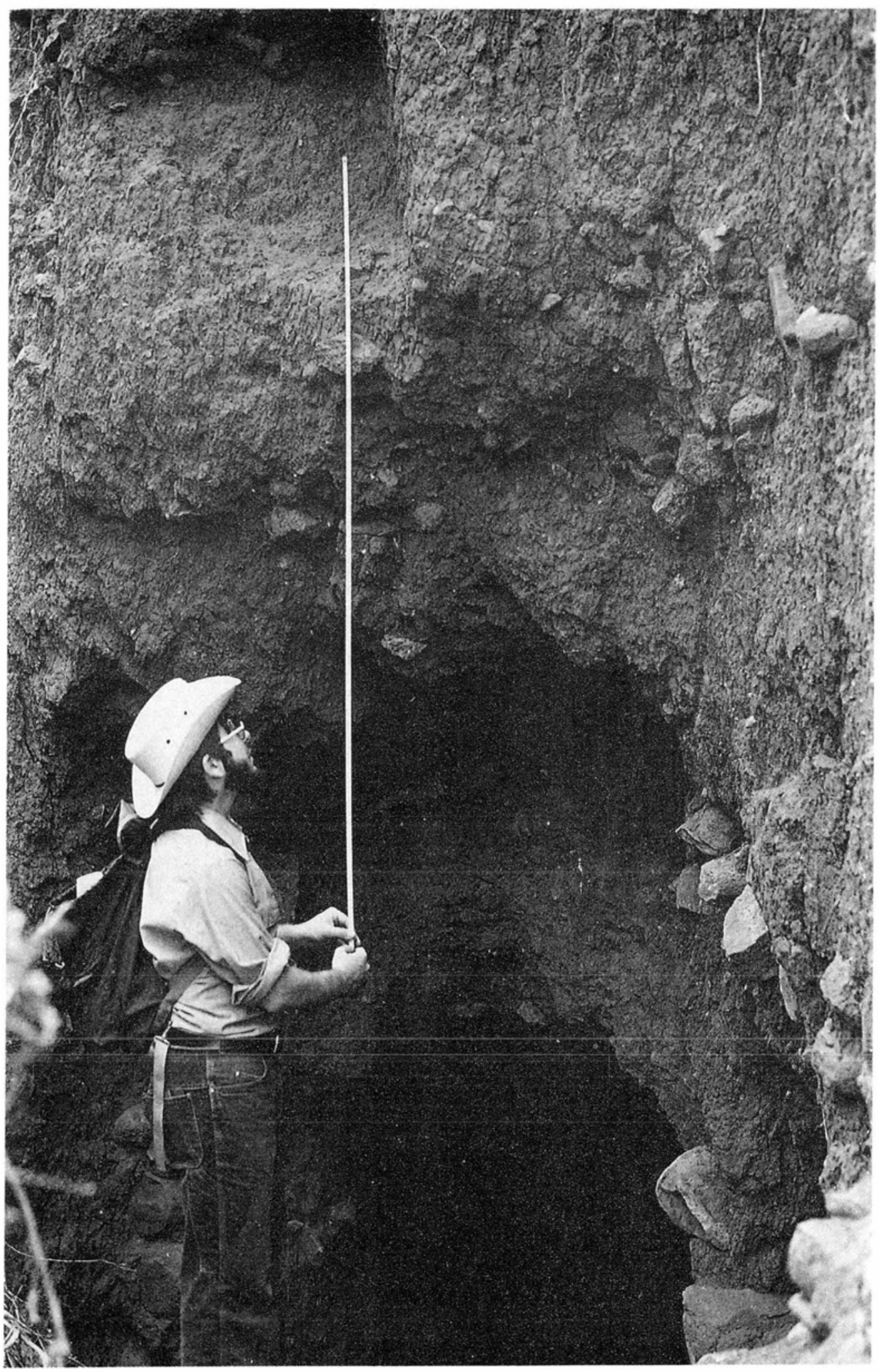

8. Profile. Pyramid “A”. Ahualulco. 
and geometries. But, as already implied, here the similarities between Teotihuacan and Teuchitlán end.

Circularity and rectangularity as governing geometries in architecture imply far more than just different preferences. In a mechanical sense, rectangularity means a grid system, which can be extended characteristically by agglutination. Circular systems, when organized into families of circles from a radical center, change dramatically in character with additions, because the circumference becomes greater. Also, these systems do not fit together using the "packing" principles that govern rectangles and squares. They do fit together using a "gear" principle, but the economics of space organization are radically different. In the overall, when the power and formality of social investment required by architecture and community settlement pattern design are considered, the architectural, morphological differences suggest strong divergences in world view and social order.

All of what has been said above, however, is only part of the picture considering Teotihuacan's relations, or lack thereof, with the highland lake districts of Jalisco and Nayarit. While I believe that architectural morphologies are more basic in understanding the social order than many other artifact types, nonetheless the other types must be considered as well. At the level of fine arts, Teotihuacan's influences into our zone of interest are remarkably few and scattered, just as the Western Mesoamerican Formative was quite free of Olmec artistic influences, the Classic periods of much of the same area show remarkably few Central Mexican influences. The question of pseudocloisonné ceramics are a case in point (Holien 1977). While superficially resembling the al fresco wares of Central Mexico, their technology and stylistic sense is very different. The roots of this style seem firmly based in the polychrome ceramics of the Late Formative, and these have clear associations with the circles. Other ceramic objects that might be of Central Mexican style include the rectangular boxes. Frequently found with late shaft-tombs (Long 1966), yet made with local clays and decorated in local styles, nonetheless their inspiration perhaps does come from the outside. Certain imports into the Teuchitlán area are very rare: no jade has ever been found; figurine styles are certainly local; but Thin Orange does appear in small quantities at the large sites of the Classic period. Pedro Armillas identified the three Thin Orange sherds from Ahualulco as "Teothihuacan III". These sherds were found in the body of the central, circular pyramid of the "A" court, and appeared on the floors that divides the Ahualulco 
phase (A.D. 200-400) from the Teuchitlán I phase (A.D. 400-700). Elsewhere in our study zone, another dozen Thin Orange sherds have been found. Thus, while a fine-arts connection surely existed, it is not all that impressive in terms of quantity, though of course its value must have been very high. Even with high value, however, Teotihuacan fine arts do not appear to have had pace-setting consequences.

I have mentioned the territorial extent of the signature, circular architecture. The boundaries of this architecture are rather easily determined: either it exists or it does not -there are no intermediate or transitional forms possible, though, of course, there are derivations in the Teuchitlán II phase (A.D. 700-900/1,000), when the symmetrical design begins to break up. One such boundary of the Classic period deserves special note in relation to Teotihuacan: that between the Atemajac Valley, where Guadalajara is situated, and the Tala-Ahualulco-Teuchitlán basin to the west. It is important to note that there are no natural barriers between these two valley systems. The rolling ridges, once heavily forested in pines, could impede no movement. However, the differences in Classic period architectural morphology between these two valleys are extremely pronounced. The Atemajac Valley has several large sites with monumental architecture which show undoubted Teotihuacan characteristics (Galván 1976 and 1984). The morphology is rectangular/square, and the architectural art includes the talud-tablero building exteriors. The talud-tablero pyramid at Ixtepete is not well understood, as it is largely buried beneath a huge Postclassic platform. The pyramids at El Grillo can be appreciated not only for their talud-tablero exteriors, but also for their square plaza layout. Other well organized site is in the Atemajac Valley, such as Las Paredes (Weigand 1986) and the fortified 55 ha citadel at Coyutla (Weigand 1987), have attested rectangular architectural features and probably date, at least in part, to the Classic period. Coyutla is an amplified Ixtepete: three great $50 \times 60 \times 4 \mathrm{~m}$ platforms, flanking spacious, rectangular plazas, bordering plazuelas with other buildings, including a cruciform pyramid. Talud-tablero architectural art was exposed by looters on a $40 \times 40 \times 12 \mathrm{~m}$ pyramid, and the general sherd cover also fits the Galván ceramic sequence for the Classic period in the Atemajac Valley. Coyutla is by far the most extensive and monumental site of the Atemajac region. Its location, as mentioned, is fortified by a combination of cliffs and terraces. The site guards an easy access from the rolling hills of Los Altos de Jalisco and the Lerma 
Valley, on a natural gateway ( $c f$. Hirth 1978) between the Lerma and the highland lake zones of Jalisco. Only one site in the Atemajac Valley has the five element architectural style: Bugambilias, located at the far western edge of the Valley, on an easy access to the obsidian rich Las Flores/La Primavera deposits. Bugamilias' relationship(s) with the other Atemajac sites cannot yet be stated, though the on-going analysis of the salvage archaeology undertaken there by Galván will undoubtably be enlightening. Such a sharp boundary between two such different architectural traditions (less than ten $\mathrm{km}$. apart at the closest points) strongly suggests a political and social frontier of pronounced dimensions. It is perhaps one of the best examples of such a frontier that we have for the Classic period in all of Mesoamerica.

If we dismiss the Teuchitlán Tradition from Mesoamerican civilization, as has already been suggested, then we are copping out of explaining why we have such diversity within a civilization, and why we have such sharp boundaries/frontiers within the overall entity. All other civilizations in the world had multiple roots, some expressions of which were as exotic as that of Teuchitlán. So, ignoring the sterile argument of wheter or not Teuchitlán was Mesoamerican, let us examine one final point, which may indeed suggest a strong structural relationship between Teuchitlán and Teotihuacan. As mentioned, Teuchitlán's signature architectural morphology has Formative roots in the area. But the trend toward pronounced site hierarchies and monumentality, in building and settlement size alike, seem to trail the developments in Central Mexico by at least a century, and perhaps a bit more, though the Teuchitlán Tradition's chronology is not well understood (Weigand 1985). Thus there exists this very real possibility: in scenario, Teothihuacan's expansive presence, as the major metropolitan component of an evolving world economy and trade structure ( $a$ la Braudel 1972 and 1982), placed pressure upon the less complex societies of Western Mesoamerica. That pressure, whether direct or indirect, whether political or economic (or both), cannot be assessed yet, but most assuredly came by way of Ixtepete, El Grillo, and Coyutla.

However, the lake district societies just to the west were too viable and far too self-reliant in resources simply to acculturate. The viability was represented by a dynamic and forceful style in both architecture and art. The self-reliance in resources includes everything from agricultural lands to obsidian to gems, plus the fact that Central Mexico apparently had little that attracted regional attention, 
resource-wise or artistically. At the 1987 Toronto Society for American Archaeology meeting, Sanders counter-postulated that the reason for the isolation of the Teuchitlán Tradition from Teotihuacan's system was that the latter needed nothing from the lake districts, and hence effected no penetration of them. But that argument can be turned around just as easily: self-sufficient systems under pressure from the outside can intensify their social and political structures in order to retain that economic independence. The intensification, patterned along exotic cultural lines, can further differentiate and distance the two systems in confrontation or contact.

Continuing the scenario: Teotihuacan's pressure was real, though we cannot know if it was economic, cultural, or political, or in combination. The sociocultural vibrancy of the Teuchitlán Tradition, plus its resource self-sufficiency, allowed it to respond by intensification of its exotic Formative heritage. The result was a distinctive architectural morphology expressing a totally different, and apparently innovative, world view, as reflected in formal design, from that of Teotihuacan. If it was formed in response, however, there is a strong structural relationship between the two areas, the kind of which is not normally evaluated in the archaeological literature. Intensification through response meant that in order to stay different from Teotihuacan, the Teuchitlán Tradition had to radically change. This apparent paradox, however, had its own logic. In Western Mesoamerica there are several examples of societies intensifying their cultural traditions, through response to radically changed political, economic, and social circumstances, in order to maintain independence. The Nayarita (a term which includes: Tecuales, Cora, Huichol, and Tepecano, Weigand $1985 \mathrm{~b}$ ) survived the first wave of Spanish conquest of the early 16 th century, and through raiding, open warfare, rustling, and acceptance of refugees, stayed independent until the early 18th century. They formed an internal frontier region with parallels to those discussed by Lattimore for Inner Asia (1951). Their refigured political structures were molded through response and compositiveness. These examples can be repeated for other areas in the New World (e.g., DiPeso 1985). The situation of response through intensification seems to be a perdurable frontier theme. ${ }^{3}$

3 This argument is complicated by the recent discovery of fairly small, five-element circles in Guanajuato (Sergio Sánchez C. and Emma G. Marmolejo M., 1990, "Algunas apreciaciones sobre el Clásico en el Bajío Central, Guanajuato", in Amalia Cardós de 
Whether or not the scenario outlined above is correct, the Teuchitlán Tradition was culturally outside the Teotihuacan network, though it must have formed part of the Mesoamerican trade structure. Teuchitlán's region experienced civilization, with craft specialization, urbanization processes, social and settlement hierarchies, etc. While Teotihuacan, for whatever reasons(s), could not incorporate it in its cultural sphere, the Central Mexican societies of the Early Postclassic period did. The 10th century A.D. was a period of profound change, wherein the nature of civilization in Western Mesoamerica was revolutionized. Habitation zones were dispersed; the circular architectural tradition was abandoned; ceramic types changed; and so forth. This process of deep sociocultural change in the west apparently parallels somewhat the transformation sweeping over the general Mayan world at about the same time. In the west, the dramatic changes are reflected in the collapse of the Atemajac-Teuchitlán frontier, and the end of the Teuchitlán Tradition. ${ }^{4}$

\section{Acknowledgements:}

The field work was accomplished under permits from the Instituto Nacional de Antropología y Historia (I.N.A.H). I am grateful to Otto Schondube and Javier Galván of the Centro Regional de Occidente for their aid. Galván was most unselfish in sharing his data and ideas. I also wish to thank Francisco Ron Siordia, Celia Carcía de Weigand, Michael Spence, James Schoenwetter, Robert Shadow, Joseph Mountjoy, Dolores Soto de Arechavaleta, Michael Cinquino, Emil Veakis, Robert Koll, Luis Figueroa, and Pedro Figueroa for their invaluable aid during the course of the field work. The intellectual debt that I owe Christopher Chippindale cannot be expressed in words. A version of this paper was first given to the symposium The Foreign Relationships of

Méndez, eda., La Epoca Clásica: Nuevos Hallazgos, Nuevas ideas. MNA/NAH, pp. 267-278). At least four of the five-element circles have been located to date in this area, so their distribution at present appears to be sporadic. In addition, these structures are associated with larger, rectangular compounds. Their functions as correlaries to these rectangular buildings, and, indeed, their exact chronological placement are yet to be determined.

4 The collapse of the Teuchitlan Tradition is explored in more detail in Weigand 1990, "Discontinuity: The Collapse of the Teuchitán Tradition and the Early Postclassic Cultures of Western Mesoamerica", in: Federica Sodi M., eda., Mesoamerica y Norte de México. Siglo IX.XII, MNAINAH, tomo 1, pp. 215-222. 
Teotihuacan, organized by Michael Spence, at the Society for American Archaeology meeting, Toronto, 1987.

\section{References Cited:}

Ackerman, James.

1984 Palladio, Pelican Books.

Alberti, Leon Battista

1986 The Ten Books of Architecture, Dover Publications.

Barnatt, John and Gordon Moir

1984 "Stone Circles and Megalithic Mathematics", Proceedings of the Prehistoric Society, 50: 197-216.

Braudel, Fernand

1972 The Mediterranean and the Mediterraneam World in the Age of Philip II, Harper and Row.

1982 The Wheels of Commerce, Harper and Row.

Chippindale, Christopher

1986 "Archaeology, Design Theory, and the Reconstruction of Prehistoric Design Systems", in Environment and Planning B: Planning and Design, pp. 445-485.

Clark, Roger and Michael Pause

1985 Precedents in Architecture, Van Nostrand Reinhold.

Deetz, James

1977 In Small Things Forgotten: The Archaeology of Early American Life, Anchor Books.

Di Peso, Charles

1985 "Displaced Native Americans of the Gran Chichimeca", in : M. Foster and P. Weigand, ed., The Archaeology of West and Northwest Mesoamerica, Westview/Praeger, pp. 431- 437.

Downing, A.J.

1969 The Architecture of Country Houses, Dover Publications.

Galván, Javier

1976 Rescate Arqueológico en el Fraccionamiento Tabachines, Zapopan, Jalisco, Cuadernos de los Centros 28, I.N.A.H.

1984 Las Tumbas de Tiro del Valle de Atemajac, Jalisco, 2 vols., ms.

Gauthier-Larouche, Georges

1974 Evolution de la Maison Rurale Traditonelle Dans la Région du Quebec, Presses de l'Université Laval.

Hirth, Kenneth

1978 "Inter-regional Trade and the Formation of Prehistoric Gateway Communities", American Antiquity, 43: 35-45.

Holien, Thomas

1977 Mesoamerican Pseudo-Cloisonné and Other Decorative Investments. PhD Dissertation, Southern Illinois University. 
Johnston, Norman

1983 Cities in the Round, University of Washington Press.

Kelly, Isabel

1980 "Ceramic Sequence in Colima: Capacha, an Early Phase", Anthropological Papers of the University of Arizona Press, 37.

Lattimore, Owen

1951 Inner Asian Frontiers of China, 2nd ed., American Geographical Society, New York.

Long, Stanley

1966 Archaeology of the Municipio of Etzatlan, Jalisco, PhD Dissertation, University of California at Los Angeles.

MacDonald, William 1976 The Pantheon, Harvard University Press.

Mercer, E. 1975 English Vernacular Houses, Her Majesty's Stationery Office, London.

Millon, René 1973 Urbanization at Teotihuacan, Mexico, Vol. I, The Teotihuacan Map, University of Texas Press.

Moholy-Nagy, Sibyl

1957 Native Genius in Anonymous Architecture, Horizon Press.

Mountjoy,Joseph

1957 "Matanchen Complex", Science, 175 (4027): 1242-3.

Oliveros, Arturo

1974 "Nuevas exploraciones en El Opeño, Michoacán", in B. Bell, ed, The Archaeology of West Mexico, West Mexican Society for Advanced Studies, Ajijic, pp. 182-201.

Palladio, Andrea 1965 The Four Books of Architecture, Dover Publications.

Rudofsky, Bernard

1964 Architecture Without Architects, Exhibit at the Museum of Modern Art, New York.

Sanders, William, Jeffrey Parsons, and Robert Santley

1979 The Basin of Mexico, Academic Press, New York.

Scott, Stuart

1985 "Core versus Marginal Mesoamerica: A Coastal West Mexican Perspective", in: M. Foster and P. Weigand, eds., The Archaeology of West and Northwest Mesoamerica, Westview/Praeger, pp. 181-191.

Stiny, George

1976 "Two Exercises in Formal Composition", Environment and Planning $B$, vol. 3, pp. 187-210.

Tzonis, Alexander and Liane Lefaivre

1987 Classical Architecture. The Poetics of Order, M.I.T. Press.

Vitruvius

1914 The Ten Books of Architecture, Harvard University Press. 
Weigand, Phil C.

1977 "The Formative-Classic and Classic-Postclassic Transitions in the Etzatlán-Teuchitlán Zone of Jalisco", in: Los Procesos de Cambio. XV Mesa Redonda, vol. 1, Sociedad Mexicana de Antropología, pp. 413. 423.

1985 "Evidence for Complex Societies During the Western Mesoamerican Classic Period", in: M. Foster and P. Weigand, eds., The Archaeology of West and Northwest Mesoamerica, Westview/Praeger, pp. 47-91.

1985b "Considerations About the Archaeology and Ethnohistory of the Mexicaneros, Tequales, Coras, Huicholes, Tepecanos, and Caxcanes of Nayarit, Jalisco, and Zacatecas", in: William Folan, ed., Contributions to the Archaeology and Ethnohistory of Greater Mesoamerica: Essays in Honor of Carroll Laverne Riley, Southern IIlinois University Press, pp. 126-187.

1986 Las Paredes, report to the Centro Regional de Occidente, I.N.A.H.

1987 Coyutla, report to the Centro Regional de Occidente, I.N.A.H.

Weigand, Phil C. and Michael Spence

1982 "The Obsidian Mining Complex at La Joya, Jalisco", in: P. Weigand and G. Gwynne, eds., Mining and Mining Techniques in Ancient Mesoamerica, Special Issue, Anthropology, vol. VI, pp. 175-188.

Wells, Camille, ed

1987 Perspectives in Vermacular Architecture, University of Missouri Press. 